\title{
DOES CORPORATE GOVERNANCE INCREASE RELATED PARTY TRANSACTION DISCLOSURE IN INDONESIA?
}

\author{
${ }^{1}$ Amrie Firmansyah, ${ }^{2}$ Pria Aji Pamungkas, ${ }^{3}$ Fardan Ma'ruf Zainuddin \\ 1,2,3 Department of Accounting, Polytechnic of State Finance STAN \\ Email: amrie.firmansyah@gmail.com
}

\begin{abstract}
The purpose of this study is to examine the effect of corporate governance (audit committee, institutional ownership, managerial ownership, and independent commissioners) on Related Party Transaction Disclosure. The data employed in this study is secondary data, financial statements from manufacturing sector companies listed on the Indonesia Stock Exchange from 2016 up to 2019. Based on the purposive sampling conducted, companies that meet the criteria in this study are 40 companies, so that the total sample is 160 observations. This study uses panel data regression analysis. This study finds that the independent commissioner has a positive effect on Related Party Transaction Disclosure. Meanwhile, the audit committee, managerial ownership, and institutional ownership do not affect Related Party Transaction Disclosure. This research indicates that the Indonesian Financial Services Authority (OJK) should supervise and tighten the rules for Indonesia listed companies, especially regarding the audit committee's or independent commissioner's requirements in listed companies.
\end{abstract}

Keywords: disclosure, corporate governance, related party

\section{INTRODUCTION}

Transactions with related parties are a common characteristic of a business. Related transactions have the objective of providing economic benefits for stakeholders and an entity by increasing efficiency to achieve corporate welfare (Pebri, 2020). On the other hand, related transactions are often misused; for example, related party transactions are used to obtain personal benefits by management and controlling shareholders, manipulating problematic company profits, transferring cash and company profits to other parts of the company (Apriani, 2015).

Related party transactions should be disclosed in financial statements because such disclosure is the key for users of financial statements to make decisions and 
EAJ (Economics and Accounting Journal) - Vol. 4, No. 1, Jan 2021 -Firmansyah et al.

understand the impact of transactions on the company, including the transfer of wealth (Apriani, 2015). PSAK No. 7 of 2015 stipulates that the entity's financial statements contain disclosures necessary to bring attention to the possibility that related parties' existence has influenced its decisions.

According to Alvionita \& Taqwa (2015), the average compliance level with mandatory disclosure by companies in Indonesia is $67 \%$. Especially for related party disclosures, the average disclosure of related party transactions carried out by them was still relatively low, which amounted to $61 \%$ (Apriani, 2015). This number is lower than the disclosure of related parties by companies connected to the government in commonwealth countries in Asia; the related party is on average $81 \%$ (Puchniac \& Varottil, 2019), and in South Africa, 77\% (Sellami \& Fendri, 2017).

One of the factors used to examined related parties' compliance is corporate governance, which consists of an audit committee, institutional ownership, managerial ownership, and independent commissioners. It is a system that regulates and controls a company that is expected to provide and increase company value to shareholders. Monitoring and controlling related party transactions is a top priority for Indonesia's corporate governance reform (Pratista, 2019). The implementation of good corporate governance is considered to maximize the company's overall management functions and lead to trust from investors that the company has been managed effectively and professionally (Aprilia, 2018).

Izzaty \& Kurniawan (2018) concluded that company size, profitability, managerial ownership, and audit committee members' number positively affected the related party's disclosure. Pebri (2020) proved that the audit committee and independent commissioners affected related party disclosure, but ownership structure had no effect on related party disclosure.

This study aims to examine corporate governance on related party transaction disclosure. It employs an audit committee, managerial ownership, institutional ownership, and independent commissioners as corporate governance components. The audit committee is a committee formed by and responsible to the Board of Commissioners to carry out the Board of Commissioners' duties and functions as Indonesia Financial Supervisory Agency No. 55 of 2015). According to Pratista (2019), the audit committee should ensure that the company has implemented and complied with all legal regulations and ensures that the company has carried out its business ethically and morally. The audit committee can influence related transactions' disclosure compliance (Sellami \& Fendri, 2017; Izzaty \& Kurniawan, 2018). The audit committee's test of 
EAJ (Economics and Accounting Journal) - Vol. 4, No. 1, Jan 2021 -Firmansyah et al.

compliance with related party transaction disclosures was rarely performed in previous studies.

Another element of corporate governance is the ownership structure. Ownership structure affects the company's disclosure (Pratista, 2019), which influences compliance is the ownership structure in a foreign party company and people in the company (Dwi et al., 2012). In this study, the ownership structure mechanism consists of institutional ownership and managerial ownership. Managerial ownership is assumed to align potential differences in interests between outside shareholders and management (Pratista, 2019). With this ownership, management will act like shareholders and carry out company management practices to increase shareholder value. Managerial ownership can affect related transaction disclosure (Pratista, 2019; Izzaty \& Kurniawan, 2018). Meanwhile, Apriani (2015) suggested that managerial ownership does not affect related party transaction disclosure. Thus, the different results need to be reinvestigated.

Furthermore, institutional ownership is the proportion of share ownership at the end of the year owned by institutions, such as insurance, banks, or other institutions (Pratista, 2019). Several parties' research states that institutional ownership does not affect related party transaction disclosure, such as Izzaty \& Kurniawan (2018).
However, these tests' rarity results in this research need to carry out more extensively.

The following element of corporate governance is the independent commissioner. Independent commissioners are expected to increase the board of commissioners' role to establish good corporate governance because those are tasked with supervising the company's directors without any pressure from any party (Pratista, 2019). Independent commissioners can influence the disclosure of related transactions (Pebri, 2020; Pratista, 2019). Meanwhile, Apriani (2015) and Izzaty \& Kurniawan (2018) state that independent commissioners do not affect related party transactions disclosure. Therefore, differences in previous studies' results indicate a need to reinvestigate the association's independent commissioner and related party transactions disclosure.

\section{LITERATURE REVIEW AND HYPOTHESIS DEVELOPMENT}

Jensen \& Mekling (1976) stated that the agency relationship is a contractual relationship between the manager (agent) and shareholders (principal). One crucial aspect of agency theory is disclosing financial information to alleviate asymmetric information by providing reports from managers to fund providers (Chaghadari \& Sukor, 2011). This financial information includes 
EAJ (Economics and Accounting Journal) - Vol. 4, No. 1, Jan 2021 -Firmansyah et al.

information on related party disclosures by management. These are considered consistent with the conflict of interest hypothesis, reflecting agency problem (Dyanty et al., 2007).

Izzaty \& Kurniawan (2018) found that the board of commissioners' role in improving company performance during tough business competition needs to be supported by committees that help carry out their duties, including the audit committee. The audit committee's role is to reduce the possibility of agency conflicts between managers and company owners. Pebri (2020) found that the audit committee positively affects the level of compliance with related party transaction disclosure. The number of audit committee members in the company can act as supervisors and examiners and encourage company management to disclose financial reports. Thus, the first hypothesis is as follows:

H1: The audit committee has a positive effect on the related party transactions disclosure

Managerial ownership is share ownership by directors, management, commissioners, or any party directly involved in making company decisions (Izzaty \& Kurniawan, 2018). It is considered to resolve agency conflicts because it can align shareholders' and managers' interests as agents. Management will benefit directly from their decisions and share the risk of making mistakes (Astasari \& Nugrahanti, 2015).
Fauziah (2015) suggested that managerial ownership positively affects the level of compliance with mandatory disclosure. According to Gunawan \& Hendrawati (2016), managerial ownership is considered one-factor influencing company compliance in implementing transparency. Managerial ownership leads to an increase in the monitoring level. Thus, the second hypothesis is as follows:

H2: Managerial ownership has a positive effect on related party transactions disclosure

Institutions have a more significant resource than the other shareholders so that institutional parties can supervise management policies more strongly than other shareholders (Murni, 2015 Wahyuni \& Mahliza, 2019). The existence of institutional ownership as part of the principal will encourage managers (agents) to disclose financial information, including related party transactions. Alvionita \& Taqwa (2015) found that institutional ownership positively affects compliance with mandatory disclosure. The number of company shares owned by an institution that is considered capable of conducting strict supervision for management in the decision-making process raises conflicts between institutional investors and management that will negatively impact the market (Alvionita \& Taqwa, 2015).

Institutional ownership can effectively control management through the monitoring process to 
EAJ (Economics and Accounting Journal) - Vol. 4, No. 1, Jan 2021 -Firmansyah et al.

affect the level of mandatory disclosure (Izzaty \& Kurniawan, 2018). The dominant institutional ownership will have

the power to influence the running of the company. Thus, the third hypothesis is as follows:

H3: Institutional ownership has a positive effect on the level of related party transaction disclosure.

The independent board of commissioners is to ensure that management decisions are in line with the owners' interests, so the presence of independent commissioners can affect the level of broader disclosure (Octaviani \& Djati, 2020). One of the main benefits of having an independent

\section{RESEARCH METHOD}

This research uses secondary data, namely financial statements of companies listed on the Indonesia Stock Exchange (IDX) from 2016 to 2019. This observation year's selection is based on the year after the revised PSAK No.7 in Indonesia in 2015 was issued so that all the data have uniform reporting standards. The population chosen in this study were manufacturing companies in the Consumer Goods Industry sub-sector that were consistently listed on the Indonesia Stock Exchange (IDX) from 2016 to 2019. Of the 58 companies, only 40 companies presented complete financial report data and annual reports related to commissioner is to protect minority shareholders and other stakeholders' interests and maintain the principle of equality (Pebri et al., 2020).

Alvionita \& Taqwa (2015) stated that the supervision carried out by independent commissioners will be free from any party's interests to guarantee the implementation of good company management. The function of independent commissioners will make the manager as the agent act by the principal's interests. Thus, the fourth hypothesis is as follows:

H4: The independent commissioners have a positive effect on related party transaction disclosure.

variables. Therefore, this study's final sample was 40 companies for four years of observation, so that there were 160 firm-years. Financial data is obtained from the Indonesia Stock Exchange website (www.idx.co.id), www.idnfinancials.com, and the company website.

The dependent variable used in this research complies with related transaction party disclosure (RPTD). It is measured and calculated based on the number of items disclosed under PSAK 7 follows Apriani (2015), Pebri et al. (2020), Aryotama \& Firmansyah (2020), Firmansyah \& Ardi (2020), Malawat et al. (2018), and Harijanto (2019). It consists of the nature of the relationship with related parties; compensation for key 
EAJ (Economics and Accounting Journal) - Vol. 4, No. 1, Jan 2021 -Firmansyah et al.

management personnel; the number of transactions, amount of balance; commitments, including terms and conditions, as well as details of guarantees; an allowance for doubtful accounts; expenses recognized in the case of doubtful accounts or writeoffs from related parties. The following formula is as follows:

RPT $=$ (Indicators of Disclosure by Companies)/(Total Number of Indicators)

Furthermore, this study has four independent variables: the audit committee, institutional ownership, managerial ownership, and independent commissioners. The proxy used in this study to measure the audit committee's size is the number of audit committees in the company. This proxy is also used by Pebri et al. (2020), Sellami \& Fendri (2017), as follows

AudCom $=$ Number of Audit Committees

This study employs institutional ownership proxy follow Amaliyah \& Herwiyanti (2019), Patricia (2014), and Hanif (2019). It is measured by the number of shares of institutional investors divided by the number of shares outstanding.

IntOwn $=(\Sigma$ Shares of institutional investors $) /(\Sigma$ Outstanding Shares $)$

The proxy of managerial ownership is obtained by dividing the number of shares owned by management by the number of shares outstanding. This proxy follows Patricia (2014) and Hanif (2019).
MOwn $=(\Sigma$ Management Shares $) /(\Sigma$ Outstanding Shares)

The proxy of independent commissioners is obtained by calculating the independent commissioners from outside the company divided by the commissioners' total number. This proxy follows Amaliyah \& Herwiyanti (2019), Ardyansah (2014), and Afnan (2014).

IndCom $=(\Sigma$ Members of KI from outside $) /(\Sigma$ All Board of Commissioners).

Furthermore, there are two control variables in this study, firm size and leverage. Firm size is measured by natural logarithmic proxy (ln) of total assets as Sellami \& Fendri (2017) and Akmyga \& Mita (2015).

Firm size $($ SIZE $)=$ Logarithm Total Assets

Leverage is measured by total debt divided by total company assets. This proxy follows Djayanti (2015). Lev $=($ Total Payable $) /($ Total Assets $)$

The data analysis test employs multiple linear regression for panel data with the following research model:

RPTDit $=\alpha 0+\beta 1$ AudComit + $\beta 2 \mathrm{MOwnit}+\beta 3$ InsOwnit + $\beta 4$ IndComit $+\beta 5$ Sizeit $+\beta 6$ Levit + cit

Where:

RPTDit = level of related party transactions disclosure the company $i$ in year $\mathrm{t}$

AudComit $=$ Number of audit committee the company $i$ in year $t$ 
EAJ (Economics and Accounting Journal) - Vol. 4, No. 1, Jan 2021 -Firmansyah et al.

MOwnit $=$ proportion of managerial ownership of company $\mathrm{i}$ in year $\mathrm{t}$

InsOwnit $=$ The proportion of institutional ownership the company $i$ in year $\mathrm{t}$

IndComit $=$ The proportion of independent commissioners the company $i$ in year $t$

Sizeit $=$ Firm size the company $i$ in year $\mathrm{t}$
Levit $=$ Leverage the company $\mathrm{i}$ in year $\mathrm{t}$

$\varepsilon i t=$ error

\section{RESULTS AND DISCUSSION}

The descriptive statistics for the variables used in the study are listed in Table 1.

Table 1 Descriptive Statistics

\begin{tabular}{llcrrrrr}
\hline & RPT & MOwnw & IndCom & ComAud & InsOwn & LEV & Size \\
\hline Mean & 0.7723 & 0.0207 & 0.3913 & 2.7937 & 0.3031 & 0.4450 & 28.463 \\
Med. & 0.7142 & $4.54 \mathrm{E}-$ & 0.4000 & 3.0000 & 0.0086 & 0.3744 & 28.285 \\
Max. & 1.0000 & 0.8485 & 1.0000 & 5.0000 & 0.9457 & 2.8998 & 32.200 \\
Min. & 0.1428 & 0.0000 & 0.0000 & 0.0000 & 0.0000 & 0.0649 & 24.865 \\
Std. Dev. & 0.1488 & 0.1163 & 0.1388 & 0.8694 & 0.3783 & 0.3707 & 1.6434 \\
Obs. & 160 & 160 & 160 & 160 & 160 & 160 & 160 \\
\hline
\end{tabular}

Source: data processed

Furthermore, the hypothesis testing results for research using the fixed-effect model are as in Table 2.

Table 2 Hypotheses Test Results

\begin{tabular}{llrrl}
\hline Var & Coef & t-Stat & \multicolumn{1}{c}{ Prob. } & \\
\hline C & -3.112 & -3.456 & 0.0008 & $* * *$ \\
AudCom & -0.0422 & -2.158 & 0.0330 & $* * *$ \\
InsOwn & -0.0522 & -0.6292 & 0.5305 & \\
MOwn & 0.0020 & 0.0117 & 0.9906 & \\
IndCom & 0.1988 & 3.271 & 0.0014 & $* * *$ \\
LEV & 0.0828 & 2.071 & 0.0406 & $* *$ \\
TA & 0.1371 & 4.305 & 0.0000 & $* * *$ \\
R2 & 0.8096 & & & \\
Adj. R2 & 0.7345 & & & \\
F-stat & 10.7753 & & & \\
Prob(F-stat) & 0.0000 & & & \\
\hline
\end{tabular}

Source: data processed

The Effect of the Audit Committee on the Level of Related Party Disclosure

Although the test result suggests that the audit committee affects related party transactions disclosure, but the direction is negative. It is assumed that the number of audit committees does not affect the related party transactions 
EAJ (Economics and Accounting Journal) - Vol. 4, No. 1, Jan 2021 -Firmansyah et al.

disclosure. This finding is not in line with Izzaty \& Kurniawan (2018) and Sellami \& Fendri (2017). It indicates that the audit committee as corporate governance in the Indonesian consumer goods industry sub-sector company is not running optimally because it turns out that the audit committee does not carry out their functions and duties properly. The frequency of meetings conducted by the audit committee has no role in increasing the related party transactions disclosure. This result may be caused by the audit committee meetings being held less effectively, where the audit committee members prioritize personal and group interests rather than the company's interests (Sofia, 2019). Moreover, the industries are the type of company with the most direct contact with consumers.

Based on the analysis results, this study found that several audit committees in the company do not have an educational background in accounting or financing that they should have to support their work as audit committees. Based on this finding, it is assumed that they accept the positions as audit committees are not based on their previous abilities or education. It is suspected based on other reasons, for example, because of their closeness to company management/owners. Therefore, selecting an audit committee that is not based on ability will make their performance unable to be maximized when they have a position as an audit committee and will not affect the company.

\section{The Effect of Institutional Ownership on the Related Party Transactions Disclosure}

The hypothesis testing result indicates that institutional ownership does not affect related party transaction disclosure. This finding is in line with Izzaty \& Kurniawan (2018). This study is inconsistent with agency theory, stating the level of institutional share ownership leads to the influence on decision-making, including information disclosed in financial statements such as related party transactions disclosures. This study also indicates that the Indonesian consumer goods industry sub-sector companies are in direct contact with consumers, so that it can be assumed that companies acting as institutional shareholders are not aware of financial reporting in detail. These companies have been monitored by the public, who act as consumers or their stakeholders. Therefore, institutional shareholders only focus on essential parts of the financial statements, such as the company's earnings and increasing their share prices.

\section{The Effect of Managerial Ownership on the Level of Related Party Disclosure}

The hypothesis test result indicates that managerial ownership does not affect related party transaction disclosure. This finding is 
EAJ (Economics and Accounting Journal) - Vol. 4, No. 1, Jan 2021 -Firmansyah et al.

in line with Pebri et al. (2020), Harijanto (2019), and Apriani (2015). However, this result is different from Izzaty \& Kurniawan (2018) and Fauziah (2015). This difference can be assumed that the average managerial share ownership in the Indonesian consumer goods industry sub-sector, which is the object of this study, is only $2.07 \%$. With such minority ownership, management does not obtain sufficient incentives to improve related party transactions disclosure compliance. This finding is consistent with agency theory that the level of managerial share ownership leads to decision-making, including the information disclosed in the financial statements.

\section{The Effect of Independent Commissioners on Related Party Transactions Disclosure}

The hypothesis testing result suggests that the proportion of independent commissioners positively affects the disclosure level of related transactions. This finding supports the research of Pebri et al. (2020), Izzaty \& Kurniawan (2018), and Pratista (2018). It is relevant to agency theory, which states that independent commissioners' existence has a role in balancing decisions to protect minority shareholders and reduce agency conflicts.

Companies with a higher
percentage of independent
commissioners are more likely to
disclose details of related party

transactions. This condition allows the general public to be relatively aware of the Consumer Goods Industry sub-sector. The selection of independent commissioners for the Consumer Goods Industry sub-sector is predominantly based on accounting and economic education backgrounds. For example, TSPC's independent commissioner is a graduate of Bachelor of Economics from Tarumanagara University. Another example is the independent commissioner of Bentoel Group, who has a Bachelor of Economics from the University of Indonesia and a Master of Business Administration from the Brussels European University. The independent commissioner from TBLA has a bachelor's degree in economics from Tarumanagara University and is the Managing Partner of KAP Justinus A Sidharta CPA Firm \& KKP Sidharta.

\section{CONCLUSION}

This study concludes that the audit committee does not affect compliance with related transaction disclosure. Companies that have more audit committee members will not perform better or more complete disclosure of related transactions. Institutional ownership does not affect compliance with the disclosure of related transactions. This finding indicates that companies with a higher number of institutional ownership will not perform better or 
EAJ (Economics and Accounting Journal) - Vol. 4, No. 1, Jan 2021 -Firmansyah et al.

more complete disclosure of related transactions. Managerial ownership does not affect compliance with related transaction disclosure. This test indicates that companies with a higher number of managerial ownership will not disclose related transactions better or more completely. Independent commissioners have a positive effect on compliance with related transaction disclosure. These test results indicate that companies with more independent commissioners will disclose related transactions better or more fully.

This study has several limitations. First, the companies that are the samples are only the consumer goods industry sub-sector companies that are listed on the Indonesia Stock Exchange, so the research results cannot be generalized to all companies. Second, this study only uses corporate governance, including the audit committee, institutional ownership, managerial ownership, and independent commissioners), while variables outside of corporate governance are not used, such as earnings quality, liquidity, and company complexity. Therefore, further research can use samples outside of other subsectors or use data from state companies outside Indonesia to compare this study's results. Future studies may use different proxies to describe corporate governance or use other independent variables.
This study indicates that the Indonesian Financial Services Authority should supervise and tighten existing regulations so that all companies listed on the IDX can be implemented, particularly concerning the requirements to become an audit committee. Furthermore, shareholders should understand more about the company's transactions, in this case, related party transactions that occur in the company. Thus, they can adequately control the company's running in which the shareholders invest their shares, even though they only have small share ownership.

\section{REFERENCES}

Akmyga, S. F., \& Mita, A. F. (2015). Pengaruh struktur corporate governance dan kualitas audit terhadap luas pengungkapan kompensasi manajemen kunci di laporan keuangan. Jurnal Akuntansi dan Keuangan Indonesia, 12(1), 19-36.

Alvionita, I., \& Taqwa, S. (2015). Pengaruh struktur kepemilikan dan mekanisme corporate governance terhadap tingkat kepatuhan mandatory disclosure. Seminar Nasional Ekonomi Manajemen Dan Akuntansi (SNEMA) Fakuktas Ekonomi, Universitas Negeri Padang, 590601.

Amaliyah, F., \& Herwiyanti, E. (2019). Pengaruh Kepemilikan Institusional, Dewan Komisaris 
EAJ (Economics and Accounting Journal) - Vol. 4, No. 1, Jan 2021 -Firmansyah et al.

Independen, dan Komite Audit terhadap Nilai Perusahaan Sektor Pertambangan. Jurnal

Akuntansi, 9(3), 171-189.

Apriani, H. W. (2015). Pengaruh Corporate Governance dan Karakteristik Perusahaan terhadap Luas Pengungkapan Transaksi Pihak Berelasi di Indonesia. Jurnal Akuntansi Indonesia, 4(1), 36-50.

Aprilia, E. A. (2018). Effect of Good Corporate Governance and Sustainability Report Disclosure Structure on Company Value and Economic Added Value As Intervening Variable. EAJ (Economics and Accounting Journal), 1(3), 225.

Aryotama, P., Firmansyah, A. (2020). The Association between Related Party Transaction And Tax Avoidance In Indonesia. AFEBI Accounting Review, 4(02), 117125.

Astasari, K. G. A., \& Nugrahanti, Y. W. (2015). Pengaruh Struktur Kepemilikan, Ukuran Komite Audit, dan Kualitas Audit terhadap Luas Pengungkapan Kompensasi Manajemen Kunci di Laporan Keuangan. Derema Jurnal Manajemen. 10(2), 162182.

Chaghadari, M. F. \& Shukor, Z. A. (2011). Corporate Governance and Disclosure of Related Party Transaction. International and Conference on Economics and Business Research, 1392-1405.
Djayanti, A. (2015). Pengaruh Ukuran Perusahaan, Profitabilitas dan Financial Leverage terhadap Praktik Perataan Laba pada Perusahaan Manufaktur yang terdaftar di Bursa Efek Indonesia. Kelola, 2(3), 1-11.

Fauziah, I. (2015). Pengaruh Mekanisme Corporate Governance terhadap Tingkat Kepatuhan Mandatory Disclosure Pasca Konvergensi IFRS. Esensi Jurnal Bisnis dan Manajemen. 5(2), 279-304.

Firmansyah, A., Ardi, A. K. (2020). Related party transactions, supply chain and cost management on firm's value: evidence from Indonesia. International Journal of Supply Chain Management, 9(3), 12011209.

Gunawan, B., \& Hendrawati, E. R. (2016). Peran Struktur Corporate Governance dalam Tingkat Kepatuhan Pengungkapan Wajib Periode Setelah Konvergensi IFRS (Studi Pada Perusahaan Manufaktur Yang Terdaftar Di Bursa Efek Indonesia). Berkala Akuntansi Dan Keuangan Indonesia, 1(1), 71-83.

Harijanto, V. N. A. (2019). Pengaruh Struktur Kepemilikan dan Ukuran Kantor Akuntan Publik terhadap Tingkat Kepatuhan Pengungkapan Transaksi Berelasi Berdasarkan PSAK No 7 tentang Pengungkapan PihakPihak Berelasi. Nominal, 
EAJ (Economics and Accounting Journal) - Vol. 4, No. 1, Jan 2021 -Firmansyah et al.

Barometer Riset Akuntansi dan Manajemen, 8(1), 59-70.

Izzaty, K. N., \& Kurniawan, P. C. (2018). Pengaruh Kinerja Keuangan, Struktur Kepemilikan dan Corporate Governance terhadap Tingkat Kepatuhan Pengungkapan Transaksi Pihak Berelasi Pasca Konvergensi IFRS. Jurnal Wira Ekonomi Mikroskil: Jwem, 8(2), 215-228.

Jensen, M. C., \& Meckling, W. H. (1976). Theory of the Firm: Managerial Behavior, Agency Costs, and Ownership Structure. Journal of Financial Economics, 3(4), 305-360.

Malawat, F. F., Sutrisno, S., \& Subekti, I. (2018). Pengaruh Pyramid of Structure Dan Pengungkapan Transaksi Pihak Berelasi Terhadap Tindakan Ekspropriasi, Dimoderasi Olehtata Kelola Perusahaan. Jurnal Akuntansi Dan Auditing, 15(1), 69-90.

Murni, Y. (2015). The Influence of Managerial Ownership, Institutional Ownership, and Voluntary Disclosure on Financial Performance and Its Implication on the Corporate Value. International Journal of Business and Management Invention. 4(5). 52-64.

Octaviani, I., \& Djati, K. (2020). The Effect of Company Size, Systematic Risk, and Independent Commissioner on Intellectual Capital Disclosure.
EAJ (Economics and Accounting Journal), 3(3),163-171.

Pebri, I. K., Diana, N., \& Junaidi, J. (2020). Pengaruh Good Corporate Governance dan Struktur Kepemilikan terhadap Tingkat Kepatuhan Pengungkapan Transaksi Berelasi Berdasarkan PSAK No. 7 tentang Pengungkapan PihakPihak Berelasi. Jurnal Ilmiah Riset Akuntansi, 9(04), 109-125.

Pratista, A. R. H. (2019). Pengaruh Corporate Governance pada Kepatuhan Pengungkapan Transaksi Berelasi Berdasarkan Pernyataan Standar Akuntansi Keuangan (PSAK) No. 7 Tahun 2015. Nominal, Barometer Riset Akuntansi dan Manajemen, 8(1), 19-30.

Sellami, Y. M., \& Fendri, H. B. (2017). The Effect of Audit Committee Characteristics on Compliance with IFRS for Related Party Disclosures. Managerial Auditing Journal, 32(6), 1-26.

Sofia, I. P. (2019). The Impact of Governance Effectiveness and Company Size on Environmental Performance. EAJ (Economics and Accounting Journal), 2(2), 76 .

Wahyuni, P. D., \& Mahliza, F. (2019). Effect of Gcg and Financial Performance on the Quality of Internet Financial Reporting. EAJ (Economics and Accounting Journal), 2(1), 52 